KÜLGAZDASÁG (ISSN: 0324-4202) 62: (5-6) pp. 62-82.(2018)

\title{
Az EU déli mediterrán politikája az Európai Beruházási Bank támogatási tevékenységének tükrében SZIGETVÁRI TAMÁS
}

Az Európai Unió számára kiemelt jelentőségü a déli Mediterráneum. A térség gazdasági fejlödésének támogatása már több mint két évtizede az Európai Unió prioritásai közé tartozik. Az arab tavasz következményei és a migrációs nyomás erösödése az utóbbi években tovább növelte a mediterrán országokkal kapcsolatos fejlesztési igények fontosságát. Az Európai Beruházási Bank (EIB) az Európai Unió fejlesztési bankjaként egyre jelentösebb hitelezési tevékenységet folytat az unión kívül, így megnött a szerepe az EU külkapcsolati (fejlesztési, szomszédsági) céljainak elérésében is. A cikk bemutatja és elemzi az EIB hitelezési gyakorlatát a mediterrán térségben, azt, hogy milyen prioritások alapján és milyen eszközökkel támogatja a térség gazdasági fejlödését, és mennyiben képes megfelelni a növekvő elvárások jelentette kihívásoknak.

Journal of Economic Literature (JEL) kódok: F21, F33, G24.

Az EU déli szomszédsága ${ }^{1}$ kiemelt jelentőségű az Európai Unió számára nemcsak az európai szomszédságpolitika résztvevőjeként, hanem az utóbbi évek fejleményei kapcsán az EU-t jelenleg érő kihívások (például migráció, terrorizmus) forrásaként is felértékelődött. Az EU a kilencvenes évek eleje óta - különböző intézményi keretek között - igyekszik támogatást nyújtani a térség országainak. Az utóbbi időben ezen támogató intézmények között felértékelődött az Európai Beruházási Bank jelentősége. Az EIB tevékenysége ugyan elsősorban az uniós tagállamokra összpontosul, azonban egyre nagyobb mértékben veszi ki a részét az unión kívüli régiók és országok támogatásában is. A cikkben elsősorban azt vizsgáljuk, hogy az EIB támogatásai mennyiben tudnak hozzájárulni a térséggel kapcsolatban megfogalmazott európai törekvések megvalósulásához.

Szigetvári Tamás, a Pázmány Péter Katolikus Egyetem docense, az MTA KRTK Világgazdasági Intézet tudományos főmunkatársa. E-mail: szigetvari.tamas@btk.ppke.hu

* A tanulmány a Bolyai János kutatási ösztöndíj támogatásával készült.

${ }^{1}$ Az EU szomszédságpolitikájában a déli Mediterráneum alatt Marokkó, Algéria, Tunézia, Egyiptom, Izrael, Jordánia, Libanon, Szíria illetve a Palesztin Önkormányzat értendő. Líbia földrajzilag ugyan része a térségnek, de az EU mediterrán politikájából kimaradt, és hasonlóképpen az EIB finnaszírozásaiból is. 
A cikk első része az EU és a déli mediterrán országok kapcsolatrendszerét elemzi: milyen kihívásokat jelent a régió az EU számára, milyen intézményrendszert hozott létre ennek kezelésére, és mennyiben képes ezek segítségével kezelni a déli Mediterráneum jelentette kockázatokat. A második rész azt tekinti át, hogy az Európai Beruházási Bank milyen prioritások alapján, milyen felhatalmazással és mely térségekben végez finanszírozási tevékenységet az unión kívül. A harmadik részben részleteiben is megvizsgáljuk az EIB tevékenységét a régióban. A hitelezési prioritások bemutatása mellett a statisztikai adatok alapján elemezzük a hitelezés országonkénti és szektorális megoszlását, illetve hogy milyen más fejlesztési intézményekkel müködik együtt a térségben. Végezetül röviden értékeljük az EIB tevékenységét a déli Mediterráneumban: mennyiben tud hozzájárulni a térséggel kapcsolatos EU-politikák érvényesüléséhez és a térség országainak fejlődéséhez, és képes lehet-e megfelelni a növekvő feladatok jelentette kihívásoknak.

\section{Az EU és a déli mediterrán országok}

A formálódó európai integráció - földrajzi, történelmi, politikai, gazdasági, kulturális kapcsolatai okán - a kezdetektől fogva közvetlenül is érdekelt és érintett déli szomszédsága, az észak-afrikai és ún. levantei országok (Szíria, Libanon, Jordánia és Izrael) biztonságában, stabilitásában és fejlődésében. Míg a hidegháború idején a kapcsolatok elsősorban kétoldalú kereskedelmi és finanszírozási megállapodásokat jelentettek, a kilencvenes évek közepétől megnőtt az igény a régió és a vele összefüggő problémák komplex kezelésére.

Az alapvető kihívást az jelentette, hogy a régió gazdaságai nem képesek lépést tartani a gyorsan növekvő népességgel, így a legtöbb országnak a növekvő munkanélküliség, a stagnáló vagy csökkenő jövedelmek miatt fokozódó társadalmi feszültségekkel kellett szembenéznie. Ezek a feszültségek pedig potenciálisan radikalizálódáshoz (iszlám fundamentalizmus), polgárháborúhoz, növekvő migrációs nyomáshoz vezethetnek. Erre a kihívásra az EU komplex, a kihívásokra választ nyújtó megoldást keresett, melynek kulcseleme a régió gazdasági prosperitásának elősegítése volt. Mindezt az EU elsősorban a gazdasági integráció (szabadkereskedelem) eszközével igyekezett támogatni, amit beruházási forrásokkal is kiegészített.

Az 1995-ben útjára indított barcelonai folyamat, amely az Euro-Mediterrán Partnerség (EMP) keretében az EU és a déli Mediterrán régió közötti kapcsolatok szorosra füzését célozta, három (politikai, gazdasági és kulturális) pillérre épült. A partnerség keretében ún. euro-med társulási megállapodásokat kötöttek a térség országaival, ami 15 év alatt a kétoldalú szabadkereskedelem megvalósítását is magába foglalta. A pénzügyi támogatások 
intézményeként létrehozták a MEDA-t (Mediterrarranean Economic Development Area Mediterrán Gazdaságfejlesztési Térség). A MEDA I. (1995-1999) keretében 4422 millió euró állt a kedvezményezett ország rendelkezésére, míg a MEDA II. (2000-2006) 5350 millió euró forrást biztosított. A pénzforrást az országstratégiákban (ún. nemzeti indikatív programokban) meghatározott célokhoz és programokhoz rendelték. Bár a mediterrán országok véleményét kikérték, a támogatási célokról Brüsszel döntött. A támogatások ugyanakkor jellemzően a helyi kormányzaton keresztül történtek, vagyis az elosztásba bevontak köre (vállalkozások, NGO-k) nagymértékben függött a helyi politikai preferenciáktól. ${ }^{2}$ A politikai és gazdasági reformokat célzó támogatások hatékonysága így elmaradt a várakozásoktól (Holden, 2008).

Az EU 2004-es bővítése után létrehozott Európai Szomszédságpolitika (European Neighbourhood Policy - ENP) együtt kezelte ugyan a déli és a keleti szomszédságot (Ukrajna, Moldova, Belorusz, kaukázusi államok), de az Euro-Mediterrán Partnerség megmaradt ezen belül is külön regionális egységként. A pénzügyi forrásokat viszont összevonták, a keleti országoknak adott TACIS ${ }^{3}$ és a MEDA 2007 után ENPI (European Neighbourhood and Partnership Instrument - Európai Szomszédsági és Partnerségi Eszköz) néven működött. Az ENPI 2007 és 2013 között 11,2 milliárd eurónyi forrással rendelkezett. Francia kezdeményezésre 2008-ban létrejött az Unió a Mediterráneumért (UfM), amely hat kiemelt mind az EU, mind a mediterrán fél számára fontos cél ${ }^{4}$ támogatásával igyekezett javítani a két régió közötti együttműködést. Ehhez kapcsolódóan hozták létre 2008-ban a Szomszédsági Beruházási Eszközt (Neighbourhood Investment Facility - NIF), elsősorban a költséges infrastrukturális projektek finanszírozására, de az eszköz a magánszektor részére nyújtott kockázatitőke-ügyleteket is támogat. A NIF az EU-költségvetés mellett az egyes EUtagállamoktól és uniós pénzügyi intézményektől származó forrásokra is épít, és a koordinációval javítja azok hatékonyságát. 2008 és 2016 között az EU-költségvetés a Szomszédsági Beruházási Eszközön keresztül összességében 1678 millió euró támogatást nyújtott, ezzel 15 milliárd eurónyi befektetést mobilizálva (ennek 60 százaléka történt a déli mediterrán országokban, 40 százalék pedig a keleti partnerekben) (European Commission,

\footnotetext{
${ }^{2} \mathrm{Ez}$ is hozzájárult ahhoz, hogy egyes társadalmi csoportok kevésbé részesültek a támogatásokban, ami rontotta a társadalmi kohéziót, és csökkentette a támogatási célok hatékony megvalósulását (Bicchi-Martin, 2016, 144. o.).

${ }^{3}$ A TACIS (Technical Assistance to the Commonwealth of Independent States and Georgia - Technikai Segítség a Független Államok Közösségének és Grúziának) programot 1991-ben indította az EU a poszt-szovjet köztársaságok támogatására.

${ }^{4}$ A hat célterület: közlekedés és városfejlődés, víz- és környezetvédelem, energia- és klímavédelem, társadalmi és civil ügyek, felsőoktatás és kutatás, valamint üzletfejlesztés.
} 
2016, 6. o.). Szintén jelentős bilaterális támogatás áramlott az EU-tagországokból a térségbe. 1995 és 2009 között Franciaország 13,8 milliárd eurónyi támogatást nyújtott, ami meghaladja az EU-támogatások összegét erre az időszakra vetítve (12,8 milliárd), de Németország (7,2 milliárd euró), Spanyolország (2,4 milliárd euró) és Olaszország (1,6 milliárd euró) is jelentős segélyező volt (Ayadi-Gadi, 2013, 8. o.)

A 2011-ben meginduló arab tavasz azonban radikális változásokat eredményezett a térségben, és megkérdőjelezte az EU eddigi kapcsolatrendszerét a térséggel. A déli mediterrán térség jelenlegi bizonytalanságai és a globális migrációban játszott erősödő szerepe mögött a térség gazdasági és politikai folyamatainak kudarcai állnak. A kétezres évek első évtizedében a gazdasági növekedés hasznát jelentős részben egy szük elit élvezte, a munkanélküliség pedig - különösen a fiatalok között - igen magas volt, ami növelte a társadalmi feszültségeket. A térség legtöbb országa a térségben a bürokrácia, a magas politikai kockázat, a rossz gazdasági struktúra miatt nem kellően versenyképes a külföldi befektetők szemében sem. A gazdasági problémák kihatottak a régió politikai stabilitására is: az évtizedek óta hatalmon lévő autoriter rezsimek meggyengültek, legitimációjukat sok országban teljesen elveszítették. Az olykor forradalmi módon megnyilvánuló elégedetlenség azonban nem tudott megnyugtató megoldást eredményezni, a radikális iszlám elöretörése tovább fokozta a térséggel kapcsolatos bizonytalanságot (Szigetvári, 2012).

Az EU mediterrán kezdeményezéseinek egyik legalapvetőbb célja az volt, hogy a régió gazdasági fejlődésének segítésével saját biztonsági kockázatát csökkentse. A gazdasági liberalizációval és gyors külgazdasági nyitással végrehajtandó reformok azonban rövid távon óriási gazdasági költségeket jelentettek a déli országok számára. Az EU - belső strukturális feladatai, illetve a keleti bővítés miatt - csak korlátozott támogatást tudott nyújtani mindehhez, és az egyes problémákra (fizetésimérleg-gondok, munkahelyteremtés) megoldást jelentő külföldi befektetések fellendülése is elmaradt. Számos terület (szolgáltatásliberalizáció, munkaerő-áramlás) egyelőre nem, vagy csak részben tárgya a két országcsoport partnerségének. A mediterrán politika tehát, amelynek célja az EU-t érő biztonsági kockázatok csökkentése lett volna, sokszor az e folyamattal ellentétes hatásokat erősítette (N. Rózsa-Szigetvári, 2018).

Az EU igyekezett reagálni az arab tavasz eseményeire. Első reakcióként az Európai Szomszédsági és Partnerségi Eszköz (ENPI)forrásait 2011 és 2013 között 1 milliárd euróval növelte, és új prioritásokkal (például inkluzív gazdasági fejlődés) bővítette (Zorob, 2017, 10. o.). Felerősítette a támogatások feltételekhez kötött odaítélését. A reformokban élenjáró országokat több forrással ,jutalmazták”, és ennek demonstrációs hatásra alapozva próbáltak 
ösztönözni a többi országot (Ayadi-Gadi, 2013, 17. o.). Az Európai Szomszédságpolitika (ENP) 2015-ös reformja és az EU 2016-os Globális Stratégiája komplex keretek között is igyekezett orvosolni a problémákat. Az Európai Unió érintett politikáinak (kül- és biztonsági, fejlesztési, szomszédsági) nagyobb koherenciájával, jelentősebb pénzügyi eszközök biztosításával, az egyes országok helyzetének és problémáinak differenciáltabb kezelésével, a társadalmi feszültséget csökkentő, szegénységcsökkentő, munkahelyteremtő és inkluzív gazdaságpolitikák támogatásával adtak új súlypontokat a mediterrán politikának (Schumacher-Bouris, 2017). Mindezek finanszírozására a most már Európai Szomszédsági Támogatási Eszköz (European Neighbourhood Instrument - ENI) keretében az EU költségvetése immár 15,4 milliárd euró támogatást nyújt a 2014 és 2020 közötti időszakban. E mellett kiemelt szerepet szán az EU az Európai Beruházási Banknak (EIB) a mediterrán politikai hatékonyságának és sikerességének biztosítására. A következőkben megvizsgáljuk, hogyan járult hozzá az EIB az EU mediterrán politikájában kitüzött célokhoz, és mennyiben felkészült a növekvő kihívásokra.

\section{Az EIB és tevékenysége az unión kívül}

Az Európai Beruházási Bank az EU hosszú távú fejlesztési hiteleket nyújtó intézménye, amelyet az Európai Gazdasági Közösséget létrehozó Római Szerződés alapján hoztak létre 1958-ban. A bank tulajdonosai az EU tagállamai, így a feladata is elsődlegesen az EU hosszú távú céljainak szolgálata. Az „AAA” hitelbesorolású EIB a tőkepiacokról finanszírozza hiteltermékeit, és nonprofit módon nyújt hitelt a tagállamokban, illetve a tagállamok számára közös érdeket jelentő projektekre (Baranyai-Halász, 2014). ${ }^{5}$ Az EIB 1963 óta folyamatosan és egyre jelentősebb mértékben támogatja az EU külső politikáit, amely mára gyakorlatilag a világ összes országát magába foglaló aktivitást eredményez. Az EIB külső hitelezése elsősorban az EU külpolitikai, szomszédságpolitikai és fejlesztési segélyezési céljait szolgálja. Más multilaterális fejlesztési bankkal összehasonlítva (IBRD, EBRD, Afrikai Fejlesztési Bank stb.) az EIB több elemében is sajátságokkal rendelkezik. Az EIB az EU-tagállamok mindegyikében és a fejlődő államokban egyszerre aktív, EU-n kívüli tevékenysége jelentős részben EU-garancia mellett történik, továbbá az EU-n kívüli kedvezményezett országok nem részvényesei az EIB-nek. Nincs saját fejlesztési célkitüzése, hanem az EU-tagállamok és intézmények által meghatározott célok érdekében tevékenykedik. Elsősorban beruházási és projektfinanszírozásra összpontosít, és csak korlátozottan vesz részt az ország- vagy

\footnotetext{
${ }^{5}$ Lásd a lisszaboni szerződést (TFEU, 309. cikkely).
} 
szektorális stratégia formálásában. Kedvezményes hiteleket csak korlátozottan nyújt, elsősorban regionális alapon (például ACP-országok ${ }^{6}$ ), és más fejlesztési bankokkal összehasonlítva jóval kisebb human erőforrással végzi a fejlett országokban történő finanszírozásait (Steering Committee, 2010, 8. o.).

Az EIB Külső hitelezési mandátuma (External Lending Mandate - ELM) az EU költségvetése által a külső finanszírozásokhoz nyújtott garanciális háttérrel működik. ${ }^{7}$ Az EIB Külső hitelezési mandátuma a bővítési és szomszédságpolitikában részt vevő országok mellett LatinAmerika és Ázsia országait is magába foglalja. Az afrikai országok nagy része az ACPországok számára a Cotonou-i megállapodás alapján müködő külön mandátum keretében részesülhet EIB-hitelekben. E mellett az EIB a Saját kockázati eszköz (Own Risk Facility ORF) keretében EU-garancia nélkül is nyújt hiteleket. Általánosságban az EU-n kívül támogatott projekteknél a magánszektor fejlesztése, a gazdasági és társadalmi infrastruktúra, a klíma- és környezetvédelemmel összefüggő és a regionális együttmüködést támogató beruházások élveznek prioritást. E mellett az EIB Külső hitelezési mandátuma az utóbbi időben az uniós vállalatok közvetlen müködőtőke-befektetéseit (FDI) is támogatja.

Az EIB esetében természetesen az Európai Unión belüli projektek vannak túlnyomó (90 százalék körüli) többségben, a fennmaradó 10 százalékon pedig 160 EU-n kívüli állam osztozik. Azonban ez az összeg is jelentős: létrejötte óta az EIB összességében 120 milliárd euró értékben helyezett ki tőkét az EU-n kívüli országokban végrehajtott projektek finanszírozására, és jelenleg évi 8 milliárd euró körül hitelezi az unión kívüli projekteket. Az első három évtizedben az afrikai, karibi és csendes-óceáni régióban lévő korábbi gyarmatok (az ún. ACP-országok) élveztek prioritást, de a hetvenes évek végétől már a mediterrán országok is jelentős kedvezményezetté váltak. A kilencvenes években azután egyértelmüen a legfőbb célrégióvá vált a Mediterráneum a nem EU-s hitelek tekintetében, jelentős részben az ekkor formálódó euro-mediterrán partnerségi folyamat kiemelt támogatása miatt (lásd az 1. táblázatot). A kétezres évektől a csatlakozó államok vették át a vezető szerepet, kezdetben a kelet-közép-európai, 2004-ben és 2007-ben csatlakozó országok, később a Nyugat-Balkán és

\footnotetext{
${ }^{6}$ Az ACP az Európai Unióval gazdasági együttműködési szerződést kötő, jelenleg77 afrikai, karibi és csendesóceáni országot foglalja magában.

${ }^{7}$ Az EU által biztosított garancia szükségessége részben az EIB alapokmányából következik, amelynek értelmében hitelezési tevékenységet csak megfelelő biztonsággal végezhet, és meg kell őrizni a bank hitelességét (még a kockázatosabb harmadik országbeli hiteleknél is). A garancia kezdetben országalapú volt, később regionális, majd 2007 óta általános (kivéve az ACP-országokat, amelyekre külön eljárási szabály vonatkozik). (European Commission, 2013, 66. o.)
} 
Törökország váltak a hitelek elsődleges kedvezményezettjeivé. A Keleti Partnerség támogatása szintén jelentős forrásokat kötött le, míg az utóbbi időben megnőtt a kül- és fejlesztéspolitikai célok érdekében támogatott nem európai (ázsiai, latin-amerikai) hitelezés aránya is. Összességében a déli mediterrán régió az EIB nem EU-s forráskihelyezéseinek negyedéhez, 32,5 milliárd euróhoz jutott, a tágan értelmezett mediterrán régió (Törökországgal és a Nyugat-Balkánnal) pedig a források majdnem felét kapta.

1. táblázat

\section{Az Európai Beruházási Bank külső finanszírozási projektjei régiónként és} időszakonként ${ }^{*}$

(Millió euró)

\begin{tabular}{|l|c|c|c|c|c|}
\hline & $1959-1989$ & $1990-1999$ & $2000-2009$ & $2010-2017$ & $1959-2017$ \\
\hline EFTA & 68 & 1101 & 1866 & 1575 & 4612 \\
\hline Csatlakozó & 982 & 871 & 17165 & 20237 & 39256 \\
\hline Kelet-Európa & 0 & 0 & 718 & 9153 & 9870 \\
\hline Mediterrán & 1533 & 6137 & 12543 & 12382 & 32596 \\
\hline ACP & 2806 & 3299 & 5551 & 7013 & 18669 \\
\hline $\begin{array}{l}\text { Ázsia és } \\
\text { Latin- } \\
\text { Amerika }\end{array}$ & 0 & 1701 & 5705 & 9814 & 17220 \\
\hline
\end{tabular}

A táblázatok adatai az EIB honlapján elérhető adatbázison alapulnak (lásd:

http://www.eib.org/projects/loan/list/index), egyes esetekben saját számításokkal is kiegészítve.

Forrás: EIB.

\section{Az EIB tevékenysége a déli mediterrán országokban}

Az EIB szerepvállalása a Mediterráneumban

Az EIB 1978 óta nyújt hiteleket a mediterrán országoknak. Az 1978 és 1995 közötti időszakban az EU kétoldalú pénzügyi és együttműködési megállapodásokat kötött a déli mediterrán országokkal. Az ötévente megújuló megállapodások nemcsak költségvetési, hanem EIB-támogatás nyújtását is lehetővé tette a térség országainak. 1978 és 1991 között a mediterrán országok 1965 millió ecu, míg az 1991 és 1995 közötti időszakban a 4. pénzügyi protokoll alapján további 1300 millió ecu hitelhez juthattak. Az 1990-ben elfogadott Új Mediterrán Politika az 1992 és 1996 közötti időszakra további 1800 millió ecu hitellehetőséget biztosított elsősorban regionális (1300 millió ecu) és környezetvédelmi (500 millió euró) projektek finanszírozására.

Az 1995-ben Barcelonában elindított Euro-Mediterrán Partnerségi folyamat keretében létrehozott MEDA-programhoz kapcsolódóan az EIB 1995 és 1999 között az Euromed programból 4808 millió euró kölcsönt biztosított, míg 2000 és 2007 közöttre az Euromed II.- 
ben 6400 millió euró állt rendelkezésre. Az EIB 2002-ben átalakította az Euromed támogatási keretet, és létrehozta a FEMIP-et (Facility for Euro-Mediterranean Invesment and Partnership - Euro-Mediterrán Beruházási és Partnerségi Pénzügyi Eszköz), amely a regionális beruházások elsődleges eszközévé vált. A FEMIP keretében 2002 óta 23 milliárd eurónyi projekt-támogatást nyújtott az EIB a térségnek.

2008-ban az Unió a Mediterráneumért (UfM) kezdeményezés finanszírozásában szintén jelentős szerep hárult az EIB-re: az Unió a Mediterráneumért hat tervezett területéből három esetében részt vesz a finanszírozásban. Ezek: a környezetvédelem (a Földközi-tenger szennyezettségének csökkentése), alternatív energiaprojektek (például naperőmüvek) finanszírozása, illetve a közlekedési infrastruktúra (kikötők, autópályák) fejlesztése. Az infrastrukturális projektek mellett létrehozták a Mediterrán Üzleti Fejlesztési Kezdeményezést (Mediterranean Business Development Initiative), amely pénzügyi és technikai segítséget is nyújt a partnerországok mikro-, kis- és középvállalkozásai számára (Joint Declaration, 2008, 20. o.).

Az arab tavasz hatására a korábbi támogatási politika negatív tapasztalataira is építve 2014 és 2020 közötti időszakban az EIB új prioritásokat jelölt ki a támogatásoknál. Az egyik elsődleges cél a magánszektor növekedésének támogatása lett, e mellett a társadalmi és gazdasági infrastruktúra fejlesztése, a környezetvédelem és a klímaváltozás elleni küzdelem a kiemelt célok. Elsősorban Marokkóban és Tunéziában indítottak új, innovatív programokat, amelyek a közösség számára központi jelentőségü gazdasági szereplők támogatására helyezik a hangsúlyt, ezáltal próbálva növelni a projektek társadalmi hatását. Ilyen lehet például a foglalkoztatás növelése, amely a régió magas munkanélküliségi rátája és az ebböl származó negatív következmények miatt is kiemelt fontosságú (EIB, 2015a, 15. o.).

Az Európai Tanács által 2016-ban elfogadott Külső Beruházási Terv (External Investment Plan - EIP) kibővítette az EIB Külső hitelezési mandátumát: külön prioritás lett a migráció gyökereinek kezelése. Az Európai Bizottság javaslatára az EU-költségvetés (MFF) félidei felülvizsgálata kapcsán az EIB Külső hitelezési mandátuma mögött álló garanciaplafon összegét 27 milliárd euróról 32,3 milliárd euróra növelték. A megemelt összegböl 1,4 milliárd a csatlakozó országok és a déli Mediterráneum országaiban a migráció kapcsán jelentkező közkiadások, 2,3 milliárd pedig a magánszektor migrációhoz kapcsolódó tevékenységének támogatására szolgál (Dobreva, 2018, 4. o.). Ezzel párhuzamosan fogadták el az ún. Gazdasági Ellenálló-képességi Kezdeményezés (Economic Resilience Initiative - ERI) létrehozását. Az ERI gyorsan mozgósítható kiegészítő pénzügyi támogatást biztosít ugyanezen régiók (Nyugat-Balkán és Dél-Mediterráneum) országaiban a fenntartható 
fejlődés, valamint a társadalmi infrastruktúra és kohézió és ezáltal a gazdasági ellenállóképesség javítására.

EIB támogatások a statisztikák tükrében Ha az egyes dél-mediterrán országok szintjén nézzük a támogatások megoszlását, akkor három kedvezményezett ország emelkedik ki: Egyiptom (8644 millió euró), Marokkó (7486 millió euró) és Tunézia (6522 millió euró). Ez a három ország nagyjából az egész időszakot tekintve hasonló helyzetben volt, együttesen a támogatások 72 százalékát kapták. Egyedül Algéria tudott a kilencvenes években felkerülni a képzeletbeli dobogóra (lásd a 2. táblázatot).

2. táblázat

EIB-projektek az egyes mediterrán országokban időszakonként (millió euró), valamint a

GDP-re és a népességre vetítve ${ }^{*}$

\begin{tabular}{|l|c|c|c|c|c|c|c|}
\hline & $1978-$ & $1990-$ & $2000-$ & $2010-$ & Összesen \\
1989 & 1999 & 2009 & 2017 & $\begin{array}{c}\text { Támogatá } \\
1978-\end{array}$ & $\begin{array}{c}\text { Támogatá } \\
\text { s/GDP }\end{array}$ & $\begin{array}{c}\text { s/népessé } \\
\mathrm{g}\end{array}$ \\
\hline Algéria & 200 & 1104 & 854 & 500 & 2719 & 12,8 & 64,7 \\
\hline Egyiptom & 404 & 1293 & 2970 & 3977 & 8644 & 17,6 & 87,0 \\
\hline Izrael & 93 & 142 & 510 & 776 & 1521 & 3,6 & 180,0 \\
\hline Jordánia & 100 & 405 & 488 & 370 & 1363 & 28,3 & 137,6 \\
\hline Libanon & 40 & 516 & 742 & 661 & 1959 & 30,7 & 321,5 \\
\hline Marokkó & 263 & 1620 & 2553 & 3050 & 7486 & 66,0 & 206,8 \\
\hline Palesztina & 0 & 217 & 68 & 54 & 340 & 35,3 & 67,3 \\
\hline Szíria & 102 & 20 & 1437 & 185 & 1744 & 18,8 & 95,4 \\
\hline Tunézia & 272 & 819 & 2797 & 2634 & 6522 & 135,3 & 559,4 \\
\hline $\begin{array}{l}\text { Észak- } \\
\text { Afrika }\end{array}$ & 0 & 0 & 10 & 62 & 72 & & \\
\hline Mediterrá & 0 & 0 & 115 & 112 & 227 & & \\
\hline n & 1533 & 6137 & 12543 & 12382 & 32596 & 21,2 & 136,3 \\
\hline Összesen & & & & & & & \\
\hline
\end{tabular}

A táblázatban az 1978 és 2017 között kapott összesített támogatást hasonlítjuk össze a 2017-es GDP- és népességadatokkal. A GDP-adatok az IMF adatai alapján, azoban a hivatalos dollár-/euróárfolyamon átszámolva kerültek az összehasonlításba.

Forrás: EIB, ENSZ, IMF. 
Mivel nagyon eltérő nagyságú és gazdasági fejlettségü országokról van szó, így érdemes megnézni, hogyan oszlanak el a támogatások népesség- és GDP-arányosan. A 2. táblázat utolsó két oszlopából jól látható, hogy mind népesség, mint GDP arányosan Tunézia volt messze a legjelentősebb kedvezményezett: népességarányosan a régiós átlag négyszerese (559 euró/lakos), GDP-arányosan a hatszorosa (135 euró/1000 euró) volt a támogatása. A népességarányos támogatás tekintetében Libanon követte, Marokkót megelőzve, míg a 99 milliós Egyiptom csak a 7. helyen állt, messze elmaradva a régiós átlagtól. GDP-arányosan Marokkó volt a második, de Egyiptom itt is az átlag alatti támogatáshoz jutott.

Az EIB régiós aktivitásának részletesebb elemzésében a továbbiakban a 2002 és 2017 közötti, a már az Euro-Mediterrán Beruházási és Partnerségi Pénzügyi Eszköz (FEMIP) égisze alatt megvalósuló projektekre összpontosítunk. A FEMIP keretében nyújtott támogatások legnagyobb kedvezményezettje is Egyiptom (6542 millió euró), Tunézia (5241 millió euró) azonban - a teljes időszakra vizsgált adatokkal ellentétben - itt utolérte, sőt megelőzi Marokkót (5240 millió euró). ${ }^{8}$ A három ország együttesen a FEMIP támogatások 73,6 százalékát kapta, vagyis a három ország dominanciája a támogatások terén a teljes időszakénál erősebb. A koncentráció további erősödését mutatja, hogy a 2010 és 2017 közötti projektek alapján 78 százalékos a három ország részesedése, míg a legutóbbi évek (20152017) projektjeinek már a 81 százalékát e három országgal írták alá. Mindez összeegyeztethető a szomszédságpolitika változó prioritásaival, amely a támogatások nagyobb koncentrációját, a reformokban élenjárók jutalmazását, és a demonstrációs hatást igyekszik erösíteni.

Ha az elfogadott és aláírt hitelprojektek számát tekintjük (lásd a 3. táblázatot), 2002 és 2017 között összesen 276 EIB-projekt indult. Ez alapján Marokkó (71 projekt) volt a legnagyobb kedvezményezett, Tunézia (55) és Egyiptom (47) előtt. A három ország együttes részesedése itt 63 százalék alatt marad, bár a 2015 és 2017 közötti időszak 43 projektje már ugyancsak 70 százalék fölötti részarányt jelent.

3. táblázat

\section{Finanszírozott projektek száma a FEMIP keretében országonként és időszakonként}

\begin{tabular}{|l|c|c|c|c|}
\hline & $2002-2007$ & $2008-2014$ & $2015-2017$ & $2002-2017$ \\
\hline Algéria & 5 & 1 & 0 & 6 \\
\hline Egyiptom & 15 & 19 & 13 & 47 \\
\hline Izrael & 3 & 7 & 3 & 13 \\
\hline Jordánia & 4 & 8 & 3 & 15 \\
\hline Libanon & 5 & 11 & 6 & 22 \\
\hline
\end{tabular}

${ }^{8}$ Ezen adatok a 4. táblázatban is megtalálhatók. 


\begin{tabular}{|l|c|c|c|c|}
\hline Marokkó & 22 & 32 & 17 & 71 \\
\hline Palesztina & 2 & 2 & 2 & 6 \\
\hline Szíria & 7 & 6 & 0 & 13 \\
\hline Tunézia & 20 & 22 & 13 & 55 \\
\hline Regionális & 9 & 16 & 3 & 28 \\
\hline Összesen & 92 & 124 & 60 & 276 \\
\hline
\end{tabular}

Forrás: EIB.

A projektek nagysága alapján ugyanakkor Egyiptom messze kiemelkedik a mezőnyben, 2002 és 2017 között 18 darab 200 millió euró fölötti szerződésböl 12-t Egyiptommal kötöttek, míg hármat Marokkóval, egyet-egyet pedig Algériával, Szíriával és Tunéziával (lásd a 4. táblázatot). A legnagyobb projektek között elsősorban energetikai és közlekedési projektek vannak: Egyiptomban erőmüvek, a földgáz cseppfolyósítását lehetővé tevő LNG-terminálok, gázcsővezeték, finomító, illetve a kairói metró és az egyiptomi légitársaság fejlesztése szerepelt, míg a többi óriáshitelt Marokkóban autópálya-építésre, Szíriában és Algériában pedig erőmü-, illetve gázvezeték-építésre fordították. Az utóbbi két évben két jelentős, a magánszektor, ezen belül is a kis- és középvállalatok támogatására hivatott, Egyiptomnak nyújtott hitelkeret is bekerült a nagy projektek közé.

Az EIB-támogatások többsége a közszférának nyújtott hitel volt, különösen igaz ez a nagy volumenű hitelek esetében. Azonban ezek között is találhatunk a magánszektor szereplőivel kötött megállapodást - ilyen volt például az a 2017-es 250 millió eurós kis- és középvállalati hitelkeret is, amit az egyiptomi Misr Bankkal írtak alá. A nagy projektek esetében is látható a párhuzam a szomszédságpolitikában megjelenő változásokkal: felértékelödtek a magánszektornak nyújtott, és lehetőleg nem a kormányzaton, hanem helyi bankokon keresztül történő támogatások.

4. táblázat

\section{A legnagyobb FEMIP-projektek}

(200 millió euró felett)

\begin{tabular}{|l|l|c|l|l|c|}
\hline Ország & Projekt & Aláírt összeg & Forma & Szektor & Aláírás éve \\
\hline Egyiptom & $\begin{array}{l}\text { Idku LNG } \\
\text { terminál }\end{array}$ & 304,5 & Magán & Energia & 2003 \\
\hline Egyiptom & Egyptair II & 290,0 & Közszektor & Közlekedést & 2004 \\
\hline Egyiptom & Idku LNG II & 234,4 & Magán & Energia & 2005 \\
\hline Egyiptom & $\begin{array}{l}\text { Egas } \\
\text { gázhálózat }\end{array}$ & 250.0 & Közszektor & Energia & 2008 \\
\hline Szíria & $\begin{array}{l}\text { Deir Ali II } \\
\text { erőmű }\end{array}$ & 275,0 & Közszektor & Energia & 2008 \\
\hline Marokkó & $\begin{array}{l}\text { ADM VI - } \\
\text { autópálya }\end{array}$ & 225,0 & Közszektor & Közlekedés & 2009 \\
\hline
\end{tabular}




\begin{tabular}{|c|c|c|c|c|c|}
\hline Algéria & $\begin{array}{l}\text { Medgaz } \\
\text { csővezeték }\end{array}$ & 500,0 & Közszektor & Energia & 2010 \\
\hline Egyiptom & $\begin{array}{l}\text { Egyptian } \\
\text { Power erőmú }\end{array}$ & 260,0 & Közszektor & Energia & 2010 \\
\hline Egyiptom & ERC finomító & 346,4 & Közszektor & Ipar & 2010 \\
\hline Egyiptom & $\begin{array}{l}\text { Giza North } \\
\text { erőmű }\end{array}$ & 300,0 & Közszektor & Energia & 2010 \\
\hline Marokkó & $\begin{array}{l}\text { ADM VII - } \\
\text { autópálya }\end{array}$ & 220,0 & Közszektor & Közlekedés & 2010 \\
\hline Marokkó & $\begin{array}{ll}\text { El-Jadida } & - \\
\text { Safi } & - \\
\text { autópálya } & \end{array}$ & 240,0 & Közszektor & Közlekedés & 2012 \\
\hline Tunézia & $\begin{array}{l}\text { ETAP South } \\
\text { Tunisia } \\
\text { gázvezeték }\end{array}$ & 380,0 & $\begin{array}{l}\text { Magán és } \\
\text { közszektor }\end{array}$ & Energia & 2014 \\
\hline Egyiptom & $\begin{array}{l}\text { Damanhour } \\
\text { gázturbinás } \\
\text { erőmű }\end{array}$ & 550,0 & Közszektor & Energia & 2015 \\
\hline Egyiptom & $\begin{array}{l}\text { Kairói metró } \\
\text { (3. vonal, } 3 . \\
\text { fázis) }\end{array}$ & 200,0 & Közszektor & Közlekedés & 2015 \\
\hline Egyiptom & $\begin{array}{l}\text { Kairói metró } \\
\text { (3. vonal, } 3 . \\
\text { fázis) }\end{array}$ & 200,0 & Közszektor & Közlekedés & 2016 \\
\hline Egyiptom & $\begin{array}{l}\text { Magánszektor } \\
\text { támogatása }\end{array}$ & 500,0 & Közszektor & Hitelkeret & 2016 \\
\hline Egyiptom & $\begin{array}{l}\text { KKV } \\
\text { támogatás } \\
\text { Misr Bankon } \\
\text { keresztül }\end{array}$ & 250,0 & Magán & Hitelkeret & 2017 \\
\hline
\end{tabular}

Forrás: EIB.

Ha az összes támogatásnál vizsgáljuk a szektorális elosztást, hasonlókat tapasztalunk (lásd az 5. táblázatot). A 2002 és 2017 között aláírt szerződések alapján a Euro-Mediterrán Beruházási és Partnerségi Pénzügyi Eszköz (FEMIP) két, az Unió a Mediterráneumért (UfM) keretében prioritásként megjelölt területen volt a legaktívabb: az energetikai projektek az aláírt pénzügyi támogatások 33 százalékát, a közlekedés 20 százalékát tették ki. Jelentősen megnőtt ugyanakkor az utóbbi időben (és a második legfontosabb területté vált) a közvetlen gazdaságtámogatási hitelek (21 százalék) aránya, e mellett az ipari támogatások (9 százalék), valamint a környezetvédelmi projektek (8 százalék) számítottak kiemelt területnek. 2011 után új prioritások jelentek meg: a városi fejlődés és az oktatás. Ezek korábban nem szerepeltek támogatási célként, részarányuk azonban egyelőre meglehetősen alacsony. 
Támogatások szektoriális megoszlása 2002 októbere és 2017 decembere között

(Millió euró)

\begin{tabular}{|c|c|c|c|c|c|c|c|c|c|c|c|c|c|}
\hline Ország & $\begin{array}{l}\text { Ener } \\
\text { gia }\end{array}$ & $\begin{array}{l}\text { Hitel } \\
\text { keret }\end{array}$ & $\begin{array}{l}\text { Közle } \\
\text { kedé } \\
\text { s }\end{array}$ & Ipar & $\begin{array}{l}\text { Víz, } \\
\text { szenny } \\
\text { víz, } \\
\text { hullad } \\
\text { ék }\end{array}$ & $\begin{array}{l}\text { Okt } \\
\text { atá } \\
\mathrm{s}\end{array}$ & $\begin{array}{l}\text { Pén } \\
\text { züg } \\
\text { yi } \\
\text { sze } \\
\text { kto } \\
\text { r }\end{array}$ & $\begin{array}{l}\text { Infra } \\
\text { struk } \\
\text { túra }\end{array}$ & $\begin{array}{l}\text { Egés } \\
\text { zség } \\
\text { ügy }\end{array}$ & $\begin{array}{l}\text { Vár } \\
\text { osf } \\
\text { ejle } \\
\text { szt } \\
\text { és }\end{array}$ & $\begin{array}{l}\text { Telek } \\
\text { omm } \\
\text { uniká } \\
\text { ció }\end{array}$ & $\begin{array}{l}\text { Szo } \\
\text { Igál } \\
\text { tat } \\
\text { áso } \\
\text { k }\end{array}$ & Összes \\
\hline Algéria & 500 & & & 81 & & & 10 & 230 & & & & & 821 \\
\hline Egyiptom & 3177 & 1358 & 1115 & 546 & 259 & & 28 & & & 45 & & 14 & 6542 \\
\hline Izrael & 391 & 75 & & 181 & 607 & & & & & & & 31 & 1286 \\
\hline Jordánia & 219 & 155 & 63 & 81 & 216 & 40 & 15 & & & & & & 789 \\
\hline Libanon & & 1021 & 135 & & 175 & & 27 & & & & & & 1458 \\
\hline Marokkó & 1420 & 460 & 1692 & 639 & 285 & 283 & 55 & 100 & 70 & 206 & & 31 & 5240 \\
\hline Palesztina & 45 & 49 & & & & & 16 & & & & & & 110 \\
\hline Szíria & 675 & 120 & 50 & 105 & 125 & & 2 & 25 & 130 & & 130 & & 1332 \\
\hline Tunézia & 1313 & 1497 & 1508 & 486 & 171 & 70 & 7 & & 110 & 56 & 100 & 14 & 5241 \\
\hline Regionális & & 30 & & & & & 231 & & & & & 32 & 261 \\
\hline Összes & 7740 & 4765 & 4563 & 2119 & 1838 & 393 & 391 & 355 & 310 & 307 & 230 & 122 & 23133 \\
\hline
\end{tabular}

Forrás: EIB [2015] és EIB.

A magánszektor hitelhez jutási lehetőségére fordított 4,7 milliárd euró fölötti összeg elsősorban a kis- és középvállalkozások támogatását szolgálták. Növekvő jelentősége a támogatástípus relatív magas munkahelyteremtő képességének is köszönhető, ami az elmúlt években prioritássá vált. A kis- és középvállalati szektor támogatására a hitelek mellett tőkerészesedés (private equity operations) formájában is sor került. Ezzel a termelőszektor tőkeszegény vállalatainak nyújtott lehetőséggel elsősorban az ipar (főként élelmiszeripar), az egészségügy, az oktatás, a turizmus és egyes technológiai ágazatok cégei éltek.

AZ EIB intézményi együttmüködései a térségben Az EIB a Euro-Mediterrán Beruházási és Partnerségi Pénzügyi Eszköz (FEMIP) projektek finanszírozása érdekében számos európai és nemzetközi pénzügyi intézménnyel is szoros együttmüködést épített ki különböző projektek (például kapacitásépítés és új regionális kezdeményezések) közös támogatására. Az utóbbi években különösen felerősödött a szinergiakeresés a támogatók részéről, hiszen a térség jelentette növekvő biztonsági kockázatok kezelése megkívánja a támogatások hatékonyságának emelését.

A legalapvetőbb természetesen az Európai Bizottsággal való kapcsolat, amelynek az Európai Szomszédságpolitika (ENP) adja a keretét. Az EIB e mellett szoros együttmüködésben van a tagállamok fejlesztési intézeteivel is, hiszen Franciaország, Németország és Spanyolország 
jelentős bilaterális támogatást nyújt a térségnek. A francia fejlesztési ügynökség, az AFD (Agence Francaise de Developpement) igen aktív a térségben, és jelentős tapasztalatokkal is rendelkezik. Az EIB az AFD-vel közösen például a víz- és csatornaellátást javító projekteket finanszíroz, 2016-ban 48 millió euró értékben a Jordániában a szír menekültek vízellátását biztosító projekt valósult meg. Az EIB és a német KfW (Kreditanstalt für Wiederaufbau) 2015 óta közösen vesz részt az Unió a Mediterráneumért (UfM) tervei között is szereplö mediterrán naperőmü projekt elökészítésében, míg a spanyol AECID-del új típusú, a mikrofinanszírozást támogató 100 millió euró értékü közös kockázatitőke-finanszírozást biztosít a régió országaiban (European Commission, 2016, 6. o.).

Az Európai Újjáépítési és Fejlesztési Banknak (EBRD) 2012-ben kibővítették a mandátumát, így már részt vehet a déli mediterrán országok fejlesztési támogatásában. Az EBRD és az EIB együttmüködése jelenleg az EU-együttmüködésben legaktívabb négy déli-mediterrán ország Tunézia, Marokkó, Egyiptom és Jordánia - kereskedelmét és versenyképességét elősegítő programot támogat. A támogatás három, egymást kiegészítő pillére épül: hosszú távú hitelkeretet biztosít helyi pénzintézeteknek a feldolgozóipari és élelmiszeripari termelői láncok támogatására. A kis- és középvállalati hitelezés támogatására a helyi pénzintézetek számára biztosít kockázatfedezeti eszközt. A harmadik pillér exporttámogatási eszközt biztosít - szintén pénzintézeti közvetítéssel - kis- és középvállalatoknak, elsősorban az exporttal kapcsolatos járulékos költségek (tervezés, számvitel, EU-szabványoknak s előírásoknak megfelelés stb.) finanszírozására, illetve pénzintézeteknek is az exporthoz kapcsolódó banki szolgáltatások működtetésére. ${ }^{9}$ Az EIB a Világbankkal (2004), az Afrikai Fejlesztési Bankkal (2005) és az Iszlám Fejlesztési Bankkal (2012) is írt alá együttmüködési megállapodást a térségbeli fejlesztési projektek koordinálásáról.

EIB tevékenységének hatása és megítélése Az EIB - bár viszonylag kis figyelem irányul rá az EU külpolitikája, de akár bővítés-, szomszédság- vagy a globális fejlesztéspolitikája kapcsán - évi 8 milliárd dolláros finanszírozási keretével valójában nagyon hatékonyan képes támogatni ezen politikák sikerességét. Az utóbbi idők eseményei, amelyek a külső és különösen a szomszédságból érezhető kihívások felerősödését eredményezték, stratégiai válaszokat követeltek az EU-tól.

\footnotetext{
${ }^{9}$ 2016-ban az első pillér 120 millió eurós támogatást jelentett, ugyanilyen nagyságú helyi forrással kibővítve, míg a második pillér további 20 millió eurót..
} 
Ezen válaszok (például a 2016-ban elfogadott Globális Stratégia) már fokozottan építenek a tervezett akciókban az EIB szerepvállalására (Újvári, 2017, 33. o.).

Felmerül azonban a kérdés, vajon mennyiben képes az EIB megfelelni a növekvő kihívásoknak. Az EIB tevékenységéről, és kiemelt módon a mediterrán régióban kifejtett aktivitásától több elemzés is készült. Ezen elemzések az EIB stratégiai és operatív tevékenysége kapcsán is megfogalmaztak kritikákat és javaslatokat.

Egyes elemzések általánosságban az EIB unión kívüli finanszírozási tevékenységét vizsgálják. Antonowitz-Cyglicka et al. [2016] elemzésükben számos kritikát fogalmaznak meg az EIB projektjei kapcsán. Ezek egyike az átláthatóság: a projektekről ritkán lehet teljes értékelést kapni, az eredményeket, hatásokat sokszor indokolatlanul is bizalmas információként kezelik, ami ellentmond az EU saját intézményeire vonatkozó átláthatósági szabályoknak. Szintén kritikaként fogalmazódott meg, hogy ügyfélként sokszor off-shore hátterü, így az adóelkerülés (vagy akár korrupcióra) gyanúját sejtető partnerek is részt vesznek. E mellett a projektekkel kapcsolatos helyi vélemények figyelembe vételét is hiányolta az elemzés: a többnyire autoriter rendszerekben a kormányzat nemcsak figyelmen kívül hagyja, hanem akár erőszakos módon is elhallgattatja a helyi közvélemény esetleges tiltakozását (Antonowitz-Cyglicka et al., 2016, 7. o.).

Az EIB tevékenységéről szóló értékelések is kiemelik az EIB beruházási projektjei esetében az értékelés és a monitoring fontosságát, illetve javaslatként fogalmazzák meg ezek javítását (Steering Committee, 2010, 25. o.). Az értékeléseknél a projektekhez kapcsolódó helyi konzultációk lefolytatását, a gazdasági, társadalmi (például emberi jogok, nemi egyenlőség) és környezeti hatásvizsgálatok és indikátorok használatának fontosságát emelik ki, illetve részben hiányolják. Hasonlóan fontos a pénzmosás, a korrupció, az adóelkerülés és a terrorizmus finanszírozásának kockázata, illetve ennek csökkentése a projektek kapcsán (Dobreva, 2018).

Jól megfigyelhető különbségek vannak a 2011 előtti és utáni értékelésekben. A 2007 és 2013 közötti időszak félidei értékelése megállapította, hogy az EIB nagyon erős eszköz lehet az EU kezében, ugyanakkor a jelenleginél több humán és pénzügyi forrást igényelne (Steering Committee, 2010, 2. o.). A dokumentum szintén kiemeli az intézményi koordináció fontosságát: mind az EU külső fejlesztési politikájában érdekelt intézményekkel, mind pedig más, globális és regionális fejlesztési intézményekkel.

A 2011 után végzett értékelések (például: de Laat et al., 2013) ugyanakkor már a 2011-es arab tavasz eseményeinek fényében értékelnek, erőteljesen reflektálva az EU-fejlesztési politika nyilvánvalóvá vált hiányosságira. A régió jelentette kihívások kezelésének egyik központi 
eleme a legtöbb szakértő szerint a munkahelyteremtés, amely leginkább alkalmas az ún. inkluzív, a társadalom széles tömegei számára is érezhető hatású gazdasági növekedés eléréséhez. Az EIB-projektek vizsgálata e tekintetben felemás eredményt hozott (EIB, 2015b). Bár az infrastrukturális beruházások potenciálisan sok munkahelyet teremtenek, a vizsgált projektek esetében a tényleges új munkahelyek száma elmaradt a várakozásoktól. Még fontosabb a tartós munkahelyteremtés képessége: itt is csak egyes projektek (például egészségügy) voltak képesek jelentős számú, hosszan fennmaradó állás teremtésére, míg az energetikai, útépítési projektek esetében ezek aránya jóval alacsonyabb volt (EIB, 2015b).

Az EIB-finanszírozások hatókörének korábban már említett szélesítése (újabb területek, szektorok támogatása) és forrásainak (illetve az uniós garanciavállalás) bővítése a változásokra adott elsődleges reakciónak tekinthető. Ez a folyamat azonban lassan megy végbe. Mint Spantig [2017, 229. o.] is megállapítja, a finanszírozási prioritások megváltozása elhanyagolható, alig érezhető a célországokban, továbbá az EIB inkább az EU, mint a célországok (gazdasági) érdekeit tartja szem előtt. Igaz, itt Spantig is hozzáteszi, hogy az EIB elsődleges célja nem egyes programok vagy reformok megvalósítása (mint például a szegénységcsökkentés), ezen célokat az EU más forrásokból támogatja.

Lesay [2013] szintén arra a következtetésre jut, hogy az EIB-nek más nemzetközi fejlesztési intézményektől eltérően soha nem volt saját fejlesztéspolitikai célja, a támogatott ország gazdasági fejlődésével kapcsolatban nem rendelkezett saját fejlesztési elképzelésekkel. Ennek is köszönhető szerinte, hogy mindeddig alapvetően a részvényesek, vagyis az EU tagállamainak érdekei voltak meghatározók. Az utóbbi években célként felértékelödött a fejlesztés, vagyis komplex megközelítést próbál megvalósítani a finanszírozással kapcsolatban, azonban ehhez nem rendelkezik megfelelő saját kapacitással. Ezért is lehet fontos az együttmüködés más, nagyobb helyismerettel és szélesebb humán kapacitással rendelkező fejlesztési intézményekkel.

\section{Következtetések}

A déli Mediterráneum az elmúlt két évtizedben kiemelt szerepet kapott az Európai Unió szomszédságpolitikájában, számos intézményes keret (EMP, ENP, UfM) jött létre, amelyek a régió gazdasági felzárkóztatását, ezáltal az EU biztonsági kockázatainak csökkentését hivatottak elérni. Az arab tavasz azonban mindezen kísérletek látványos kudarcát mutatták: a felzárkóztatásnak a déli országok kereskedelmi integrációjára építő megközelítése korlátozott sikereket ért el, a politikai és részben gazdasági reformok hiánya, a magas társadalmi költségek (munkanélküliség, szegénység) pedig éppen azokat a biztonsági kockázatokat 
erősítették, amelyek ellen az EU küzdeni próbált. Az EU-nak ezért új megközelítésre van szüksége, jelentősebb forrásokat kell a régió fejlesztésére fordítania, és mindezt hatékonyabb módon kell felhasználni.

Az Európai Beruházási Bank, amely az EU fejlesztési bankjaként jött létre, egyre jelentősebb szereplővé válik az EU globális és regionális szerepvállalásának finanszírozásában és támogatásában. A szervezet által követendő célkitüzéseket az Európai Unió prioritásai jelölik ki, így az EU Globális Stratégiája, illetve a mediterrán térséggel kapcsolatos politikái meghatározzák azokat a kereteket, amelyek között az EIB finanszírozásai zajlanak.

Az EIB mediterrán térségbeli hitelezését elemezve azt láthatjuk, hogy az elmúlt években jól nyomon követhetők az EU mediterrán politikájában bekövetkező változások. A források erőteljesen koncentráltak, a reformokban élen járó országok (Tunézia, Marokkó) arányaiban jóval nagyobb támogatást kapnak, mint a térség legnépesebb állama, Egyiptom, míg az euromed kapcsolatokban kevésbé aktív Algéria, vagy a korábban hasonló politikát folytató (jelenleg pedig az országban dúló harcok miatt kieső) Szíria alig jut forrásokhoz. A támogatások szektorális fókuszát a nagy infrastrukturális ágazatok, az energia és a közlekedés teszik ki, az EIB támogatásával épülő erőmüvek, autópályák fontos elemei a mediterrán országok gazdasági felzárkózásának. Az utóbbi években végbemenő hangsúlyeltolódás felértékelte ugyanakkor a gazdasági szereplők közvetlen támogatását, ezen belül is elsősorban a kis- és középvállalkozásoknak nyújtott hitelek, illetve a kockázati alapok révén nyújtott tőkerészesedések formájában.

Az EIB tevékenységét azonban továbbra is számos kritika éri, a korlátozott átláthatóság, a gyenge monitoring és értékelési eljárás, a projektekkel kapcsolatos jogsértések nem megfelelő kezelése miatt. Mindez szükségessé tenné, hogy az elkövetkezendő években az EIB egyre jelentősebbé váló külső finanszírozási tevékenysége növekvő súlyának megfelelő személyzeti és strukturális feltételek mellett és az EU átláthatósági szabályainak következetesebb alkalmazásával valósuljon meg. E mellett a támogatott fejlesztési projektek növekvő komplexitása várhatóan azt is szükségessé teszi, hogy az EIB az egyszerü projektfinanszírozáson túl a jövőben nagyobb figyelmet fordítson azok fejlesztéspolitikai összefüggéseire is.

\section{Felhasznált irodalom}

Antonowicz-Cyglicka, Aleksandra et al. [2016]: Going abroad. A critique of the European Investment Bank's External Lending Mandate. CEE Bankwatch Network. Letölthető: https://bankwatch.org/wp-content/uploads/2016/11/going-abroad-EIB.pdf 
Ayadi, Rym - Gadi, Salim [2013]: The Euro-Mediterranean Partnership and Development Assistance: Past Trends and Future Scenarios. MEDPRO Technical Report, No. 32/március.

Baranyai László - Halász Zsolt [2014]: Az Európai Beruházási Bank az Európai Unió intézményrendszerében. Közgazdasági Szemle, LXI. évf., 4. sz., 404-413. o.

Bicchi, Federica - Martin, Mary [2016]: Talking Tough or Talking Together? European Security Discourses towards the Mediterranean. In: Richard Youngs (ed.): Twenty Years of Euro-Mediterranean Relations. Routledge, London - New York, 134-153. o.

de Laat, Bastiaan et al. [2013]: Operations Evaluation. Ex post evaluation of EIB's Investment Fund Operations in FEMIP and ACP countries. Synthesis Report, European Investment Bank, Luxembourg.

Dobreva, Alina [2018]: Guarantee Fund for External Action and EIB external lending mandate. Briefing - EU Legislation in Progress, European Parliament, február.

EIB [2010]: Union for the Mediterranean. Role and vision of the EIB. European Investment Bank, Luxembourg.

EIB [2015a]: FEMIP Annual Report 2014. European Investment Bank, Luxembourg.

EIB [2015b]: FEMIP. Study on the employment impact of EIB infrastructure investments in the Mediterranean partner countries. Summary Report. European Investment Bank, Luxembourg.

EIB [2017]: Southern Neighbourhood \& FEMIP Trust Fund Annual Report 2016. European Investment Bank, Luxembourg.

European Commission [2013]: Impact Assessment - EIB external mandate 2014-2020. DG ECFIN, SWD(2013) 179 final.

European Commission [2016]: Neighbourhood Investment Facility. Operational Annual Report 2016. European Union, Luxembourg.

European Commission [2017]: Report on the 2016 EIB activity with EU Budget Guarantee. COM (2017) 767 final (SWD (2017) 460final).

Holden, Patrick [2008]: Development through integration? EU aid reform and the evolution of Mediterranean aid policy. Journal of International Development, Vol. 20., No. 2., 230244. o.

Joint Declaration [2008]: Joint Declaration of the Paris Summit for the Mediterranean, '3 July, Paris. Letölthető: https://ec.europa.eu/research/iscp/pdf/policy/paris_declaration.pdf Lesay, Ivan [2013]: Discoursing development: the case of the European Investment Bank. Nova Economia, Vol. 23., No. 2., 429-462. o. 
N. Rózsa Erzsébet - Szigetvári Tamás [2018]: Az EU és a déli Mediterráneum: együttmüködés kihívásokkal. In: Éltető Andrea - Szijártó Norbert (szerk.): Változó Európa a változó világban. Budapest, MTA KRTK Világgazdasági Intézet, 317-340. o.

Schumacher, Tobias - Bouris, Dimitris [2017]: The 2011 Revised European Neighbourhood Policy: Continuity and Change in EU Foreign Policy. In: Schumacher, Tobias - Bouris, Dimitris (eds.): The Revised European Neighbourhood Policy. Continuity and Change in EU Foreign Policy. London, Palgrave - Macmillan, 1-33. o.

Spantig, Lisa [2017]: International financial institutions: business as usual in Tunisia? In: Tasnim Abdelrahim et al: Tunisia's International Relations since the 'Arab Spring'. Transition Inside and Out. Routledge, Abingdon - New York, 215-237. o.

Szigetvári Tamás [2012]: Az "arab tavasz" gazdasági vonatkozásai. Külügyi Szemle, 11. évf.,1. sz., 85-102. o.

Steering Committee [2010]: European Investment Bank's external mandate 2007-2013. Mid-

Term Review. Report and recommendations of the Steering Committee of "wise persons". Letölthetö:

http://www.eib.org/attachments/documents/eib_external_mandate_2007-2013_midterm_review.pdf

Újvári, Balázs [2017]: The European Investment Bank: An Overlooked (f)actor in EU External Action? Egmont paper, 94, június.

Zorob, Anja [2017]: Analysing the economic and financial relations between the European Union and the South Mediterranean Countries. Report. EuroMed Rights, Brussels. 